\title{
HUBUNGAN KARAKTERISTIK INDIVIDU DAN SIKAP KERJA TERHADAP KELUHAN MUSKULOSKELETAL PADA PENGRAJIN BATIK TULIS
}

\author{
Candralega Bibit Saputro ${ }^{1}$, Mulyono ${ }^{2}$, Septa Indra Puspikawati ${ }^{3}$ \\ ${ }^{1}$ Program Studi S1 Kesehatan Masyarakat PSDKU Universitas Airlangga di Banyuwangi \\ 2 Departemen Keselamatan dan Kesehatan Kerja, Program Studi S1 Kesehatan Masyarakat FKM \\ UNAIR \\ ${ }^{3}$ Departemen Gizi Kesehatan, Program Studi S1 Kesehatan Masyarakat PSDKU UNAIR di \\ Banyuwangi \\ can.lega.bibit-2014@fkm.unair.ac.id
}

\begin{abstract}
Musculoskeletal complaints are one of the problems that is often encountered by workers, batik craftsmen is a kind of job that has no exception for this case. Because of its sitting position, sits with a back bent for too long that makes the back spine bending over, Batik craftsmen having a risk of musculoskeletal complaints due to of this work behaviour. This study aims to determine the relationship between individual and behavior with musculoskeletal complaints on batik craftsmen in Virdes Batik Collection. This study included observational research with cross sectional design. The sample in this study amounted to 23 peoples with sampling using simple random sampling. Data is obtained from the interview to find out the individual characteristics of batik craftsmen, the interview is using Nordic Body Map (NBM) questionnaire to find out the musculoskeletal complaints and the observations using Rappid Upper Limb Assessment (RULA) method to determine the work attitude of the batik craftsmen. The results showed that batik craftsmen in Virdes Batik Collection majority of female craftsmen, age $\geq 30$ years, period of work $\geq 5$ years and no smoking habit. For work attitudes performed included in the category of moderate risk with moderate musculoskeletal complaints. The result of statistical test using Chi Square with $\alpha=0,05$ showed significant relation between sex ( $p=$ $0,014<0,05)$, age $(p=0,001<0,05)$, period of work $(p=0,003<0,05)$, and work attitude $(p=$ $0,000<0.05)$ with musculoskeletal complaints. There was no significant relation between smoking habits and musculoskeletal complaints ( $p=0.247>0.05$ ).
\end{abstract}

Keywords: Musculoskeletal Complaints, Batik Craftsmen, Work Attitude

\begin{abstract}
ABSTRAK
Keluhan muskuloskeletal merupakan salah satu masalah yang sering ditemui oleh pekerja tak terkecuali pengrajin batik. Pengrajin batik berisiko terkena keluhan muskuloskeletal dikarenakan jenis pekerjaannya yang dilakukan dengan posisi duduk dengan posisi punggung membungkuk dalam waktu yang lama. Penelitian ini bertujuan untuk mengetahui hubungan karakteristik individu dan sikap kerja dengan keluhan muskuloskeletal pada pengrajin batik tulis di Virdes Batik Collection. Penelitian ini termasuk penelitian observasional dengan rancangan cross sectional. Sampel dalam penelitian ini berjumlah 23 orang dengan pengambilan sampel menggunakan simple random sampling. Data didapatkan dari hasil wawancara untuk menetahui karakteristik individu, wawancara menggunakan kuesioner Nordic Body Map (NBM) untuk mengetahui tingat keluhan muskuloskeletal dan observasi dengan metode Rappid Upper Limb Assessment (RULA) untuk menentukan sikap kerja. Hasil penelitian menunjukkan bahwa pengrajin batik di Virdes Batik Collection mayoritas pengrajin berjenis kelamin perempuan, umur $\geq 30$ tahun, masa kerja $\geq 5$ tahun dan tidak mempunyai kebiasaan merokok. Untuk sikap kerja yang dilakukan termasuk dalam kategori risiko sedang dengan tingkat keluhan muskuloskeletal sedang. Hasil uji statistik menggunakan Chi Square dengan $\alpha=0,05$ menunjukkan adanya hubungan yang significan antara jenis kelamin $(\mathrm{p}=0,014<0,05)$, umur $(\mathrm{p}=0,001<0,05)$, masa kerja $(\mathrm{p}=0,003<0,05)$, dan sikap kerja $(\mathrm{p}=0,000<0,05)$ dengan keluhan muskuloskeletal. Tidak ada hubungan antara kebiasaan merokok dengan keluhan muskuloskeletal $(\mathrm{p}=0,247>0,05)$.
\end{abstract}

Kata Kunci : Keluhan Muskuloskeletal, Pengrajin Batik, Sikap 


\section{PENDAHULUAN}

Industri di Indonesia baik formal maupun informal kini semakin berkembang pesat seiring dengan kemajuan era industrialisasi global. Hal ini dapat terlihat dari semakin banyaknya perindustrian di Indonesia, mulai dari perusahaan yang bersekala kecil hingga bersekala besar yang kini semakin maju. Perkembangan tersebut tentunya memiliki dampak positif dan negatif. Menurut Nurdin (2015) dampak positif dari berkembangnya perindustrian di indonesia yaitu semakin meningkatnya laju pertumbuhan ekonomi serta dapat meciptakan lapangan kerja baru bagi maysarakat. Menurut Lindawati (2015) industri informal mempu menyerap tenaga kerja baik dikota maupun didesa sebanyak 70 juta orang pada tahun 2013/2014. Sedangkan dampak negatif dari berkembangnya perindustrian di Indonesia yaitu dapat menimbulkan risiko terhadap tenaga kerja serta lingkungan apabila apabila tidak dikelola dengan baik. Salah satunya, penelitian yang dilakukan oleh Senjayani dan Tri (2017) menunjukkan bahwa terdapat 17 risiko yang dapat ditimbulkan pada pekerjaan bongkar muat peti kemas.

Salah satu industri informal yang kini sedang berkembang pesat di Indonesia adalah industri batik. Hal ini dapat terlihat dari semakin diminatinya batik hingga kancah internasional. Tahun 2009 batik masuk kedalam Representative List of the Intangible Cultural Heritage of Humanity atau warisan budaya tak benda yaitu penghargaan warisan budaya indonesia yang telah diakui oleh UNESCO. Menurut Savitri,dkk., (2015) proses pembuatan batik tulis biasanya memakan waktu hampir satu bulan untuk menghasilkan selembar kain batik yang berkualitas tergantung motif dan corak yang dihasilkan. Motif dan corak yang dihasilkan dari batik diperoleh dari proses mencanting. Proses mencanting memerlukan kesabaran, ketelitian dan kehati-hatian karena malam yang digunakan sangat panas. Proses mencanting dilakukan dengan posisi duduk dikursi kecil atau biasa disebut dingklik dengan waktu yang lama.

Salah satu fator risiko dari pekerjaan membatik adalah keluhan muskuloskeletal. Hal tersebut terjadi karena pekerjaan membatik dilakukan dengan posisi duduk dikursi yang pendek (dingklik). Penggunaan kursi yang pendek tersebut mengakibatkan sikap kerja menjadi tidak alamiah karena posisi punggung yang membungkuk. Menurut Tarwaka (2015) semakin jauh posisi tubuh terhadap gravitasi tubuh maka akan semakin besar pula keluhan muskuloskeletal yang dirasakan. Selain sikap kerja faktor individu juga berpengaruh terhadap terjadinya keluhan muskuloskeletal diantaranya yaitu jenis kelamin, umur, masa kerja, dan kebiasaan merokok (Tarwaka, 2015).

Beberapa penelitian tentang muskuloskeletal telah banyak dilakukan diantaranya yaitu penelitian yang dilakukan oleh Umami (2014) pada pengrajin batik tulis yang menyatakan bahwa pekerja yang berusia $\geq 30$ tahun, mempunyai masa kerja $\geq 5$ tahun dan sikap kerja yang tidak ergonomis lebih banyak terkena keluhan muskuloskeletal. Penelitian juga dilakukan oleh Lindawati (2015) yang menyatakan bahwa pengrajin batik yang berjenis kelamin perempuan lebih berpotensi terkena keluhan muskuloskeletal dibandingkan dengan laki-laki. Penelitian juga dilakukan oleh Zakaria (2016) yang menyatakan bahwa ada hubungan yang signifikan anatara kebiasaan merokok dengan keluhan muskuloskeletal. Restuputri (2018) menyatakan bahwa keluhan yang dirasakan oleh pengrajin batik yaitu $100 \%$ merasa sakit pada bagian lengan atas bagian kiri, $87 \%$ merasa sakit bagian punggung, dan sebanyak $75 \%$ pengrajin merasa sakit pada bagian leher bagian bawah, bahu kiri, bahu kanan, dan tangan bagian kanan.

Sanggar Virdes Batik Collection merupakan salah satu sanggar batik tertua dan telah banyak dikenal di Kabupaten Banyuwagi. Letak dari sanggar batik Virdes Batik Collection yaitu di Desa Tampo, Kecamatan Cluring, Kabupaten Banyuwangi. Hasil karya dari Virdes Batik Collection kini sudah banyak menyebar mulai dari skala daerah, nasional hingga internasional. Hasil produksi dari Virdes Batik Collection yaitu batik tulis, batik cap, batik sutra, dan berbagai macam batik khas banyuwangi. Pengrajin batik di Virdes Batik Collection banyak yang berjenis kelamin perempuan. Hal tersebut dikarenakan proses pengerjaan batik memakan waktu yang lama dan membutuhkan kesabaran dan ketelitian. 
Proses pengerjaan batik di Virdes Batik Collection banyak dilakukan dengan posisi duduk di kursi yang kecil (dhingklik). Hal tersebut mengakibatkan sikap kerja pengrajin menjadi membungkuk yang dapat mengakibatkan keluhan muskuloskeletal.

Oleh karena itu tujuan dari penelitian ini adalah untuk mengetahui gambaran karakterisitik individu dan sikap kerja terhadap keluhan muskuloskeletal pada pengrajin batik tulis di Virdes Batik Collection.

\section{METODE}

Penelitian ini masuk dalam penelitian analitik observasional. Berdasarkan waktu, penelitian ini termasuk penelitian cross sectional. Sampel yang digunakan dalam penelitian ini sebanyak 23 orang pengrajin batik yang dipilih menggunakan sample random sampling. Waktu penelitian ini dalakukan pada bulan mei tahun 2018 di Virdes Batik Collection. Varibel yang diteliti pada penelitian ini yaitu umur, jenis kelamin, masa kerja, kebiasaan merokok, sikap kerja, dan keluhan muskuloskeletal.

Data pada penelitian ini diperoleh dari hasil wawancara dan observasi. Wawancara dilakukan untuk mengetahui karakteristik individu dan keluhan muskulokskeletal yang dilakukan pada saat jam istirahat. Penilaian keluhan muskuloskeletal ini melalui metode wawancara dengan menggunakan kuesioner Nordic Body map (NBM) yang berisi gambar anggota tubuh dan skor tingkat keluhan yang dirasakan pengrajin batik. Pemberian skor 0 dilakukan apabila pengrajin tidak merasa sakit, skor 1 apabila merasakan sedikit sakit, skor 2 apabila merasakan sakit, dan skor 3 diberikan apabila merasakan sangat sakit. Hasil skor kemudian dijumlah dan dimasukkan kedalam kategori penilaian muskuloskeletal. Total skor 020 termasuk dalam kategori rendah, 21-41 masuk dalam kategori sedang, 42-62 masuk dalam kategori tinggi, 63-84 masuk dalam kategori sangat tinggi. Observasi dilakukan untuk menganalisis sikap kerja dengan mengguakan metode Rapid Upper Limb Assessment (RULA), yaitu dengan mendokumentasikan pengrajin batik dalam bentuk foto saat pengrajin batik bekerja. Hasil foto kemudian diukur sudut tubuhnya dan dianalisis menggunakan metode RULA. Penilaian dilakukan dengan membagi menjadi dua bagian yaitu grub A yang terdiri dari lengan atas, lengan bawah, dan pergelangan tangan dan grub B yang terdiri dari leher, badan, dan kaki. Hasil skor grub A dan grub B kemudian dimasukkan kedalam tabel $\mathrm{C}$ untuk mengetahui tingkat risiko. Skor 1-2 menunjukkan bahwa sikap kerja normal, skor 3-4 mungkin perlu perubahan dalam beberapa waktu kedepan, skor 5-6 segera dilakukan perubahan, skor 7 perubahan sekarang juga.

Analisis data yang dilakukan dalam penelitian ini yaitu dengan menyajikan data berupa tabel distribusi, frekuensi, persentase, dan tabulasi silang dari masingmasing variabel penelitian yang meliputi data umur, jenis kelamin, masa kerja, kebiasaan merokok, sikap kerja, dan keluhan muskuloskeletal pada pengrajin batik agar penyampaian hasil dapat dilakukan dengan mudah dipahami. Uji $C h i$ Square dilakukan untuk mengetahuai hubungan antar variabel. Nilai $p$ dapat dikatakan bermakna apabila nila $p<\alpha(0,05)$.

\section{HASIL}

Berdasarkan hasil penelitian menunjukkan bahwa pengrajin batik di Virdes Batik Collection mayoritas berjenis kelamin perempuan yaitu sebanyak 14 pengrajin dan yang berjenis kelamin lakilaki sebanyak 9 pengrajin. Distribusi kelompok umur pengrajin batik yaitu sebanyak 17 pengrajin mempunyai umur $\geq 30$ tahun dan 6 pengrajin mempunyai umur $<30$ tahun. Masa kerja pengrajin batik mayoritas mempunyai masa kerja $\geq 5$ tahun yaitu sebanyak 16 pengrajin dan pengrajin yang mempunyai masa kerja $<5$ tahun sebesar 7 orang pengrajin. Sementara untuk kebiasaan merokok, 18 orang pengrajin batik tidak mempunyai kebiasaan merokok dan sebesar sebanyak 5 orang pengrajin batik mempunyai kebiasaan merokok.

Penilaian sikap kerja pada penelitian ini menggunakan metode RULA. Berikut ini merupakan salah satu contoh penilaian sikap kerja pada pengrajin batik di Virdes Batik Collection. 


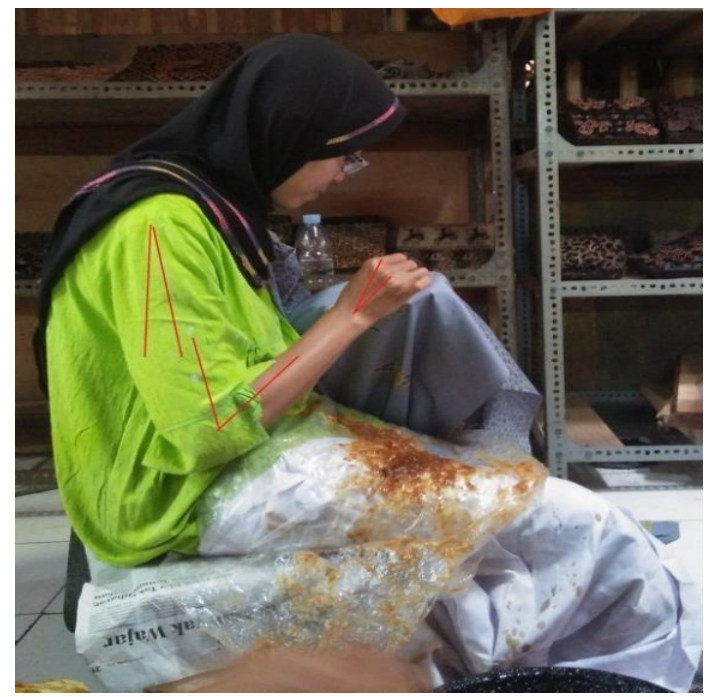

Gambar 1. Penilaian Sikap Kerja Grup A

Gambar 1 menunjukkan bahwa posisi lengan atas pengrajin batik membentuk sudut $<20^{\circ}$, maka penilaian pada lengan atas diberi skor +1 . Posisi lengan bawah membentuk sudut $<60^{\circ}$ kearah depan maka pada lengan bawah mendapa skor +2 . Posisi pergelangan tangan membentuk sudut $<15^{\circ}$ yang artinya pada pergelangan tangan mendapat skor +2 . Pergelangan tangan pada pengrajin batik tidak memutar sehingga mendapatkan skor +1 . Hasil skor posisi lengan atas, lengan bawah, dan pergelangan tangan kemudian dimasukkan kedalam tabel A dan didapatkan skor grub A +2. Posisi membatik merupakan posisi kerja yang statis $>10$ menit, maka pada penilaian skor grub A ditambah +1 . Jadi skor akhir akhir dari grub $\mathrm{A}$ adalah +3 .

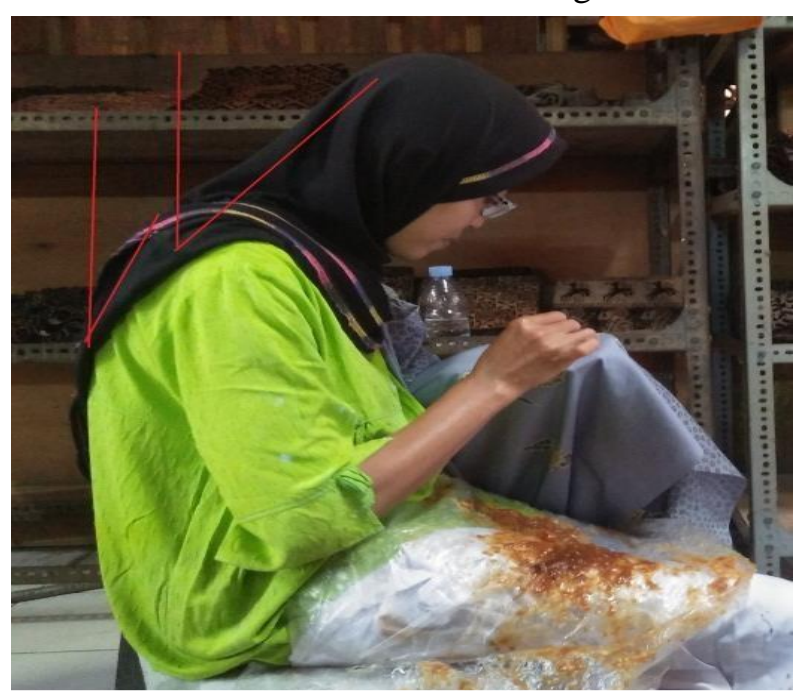

Gambar 2. Penilaian Sikap Kerja Grup B 
Posisi leher pada gambar 2 membentuk sudut $>20^{\circ}$, maka pada posisi leher mendapatkan skor +3 . Posisi badan pada gambar 2 membentuk sudut $20^{\circ}$, maka pada posisi badan mendapat skor +3 . Untuk posisi kaki pengrajin batik dalam keadaan seimbang, maka untuk posisi kaki mendapat skor +1 . Hasil skor penilaian posisi leher, posisi tubuh, dan posisi kaki kemudian dimasukkan kedalam tabel $\mathrm{B}$ dan didapat hasil skor grub B yaitu +4 .

Hasil skor dari grub A dan grub B kemudian dimasukkan kedalam tabel $\mathrm{C}$ dan didapatkan hasil akhir +4. Skor akhir +4 jika dimasukkan kedalam kategori risiko masuk kedalam tingkat risiko sedang. Hasil penilaian mengenai sikap kerja di Virdes Batik dibagi menjadi 4 kriteria yaitu rendah, sedang, tinggi, dan sangat tinggi. Dari wawancara didapat hasil bahwa sebanya 4 orang pengrajin batik di Virdes Batik Collection mengalami keluhan muskuloskeletal tingkat rendah, 16 orang pengrajin mengalami tingkat keluhan sedang Collection, 3 orang pengrajin mengalami tingkat keluhan tinggi, dan tidak ada pengrajin yang mempunyai tingkat keluhan sangat tinggi. Hasil penilaian dari wawancara menggunanakan kuesioner Nordic Body Map didapatkan hasil bahwa 4 pengrajin batik pengrajin batik di Virdes Batik Collection mengalami keluhan muskuloskeletal tingkat sedang, 16 orang pengrajin mengalami keluhan muskuloskeletal tingkat sedang, 3 orang pengrajin mengalami keluhan muskuloskeletal tingkat tinggi dan tidak ada pengrajin batik yang merasakan keluhan muskuloskeletal yang sangat tinggi.

Tabel 1. Hubungan Jenis Kelamin dan Keluhan Muskuloskeletal Pengrajin Batik Tulis

\begin{tabular}{|l|c|c|c|c|c|c|c|c|c|c|}
\hline \multirow{3}{*}{ Kenis } & \multicolumn{10}{|c|}{ Keluhan Muskuloskeletal } \\
\cline { 2 - 11 } & \multicolumn{2}{|c|}{ Rendah } & \multicolumn{2}{|c|}{ Sedang } & \multicolumn{2}{c|}{ Tinggi } & \multicolumn{2}{c|}{ Sangat Tinggi } & \multicolumn{2}{c|}{ Total } \\
\cline { 2 - 11 } & $\mathbf{n}$ & $\mathbf{\%}$ & $\mathbf{n}$ & $\mathbf{\%}$ & $\mathbf{n}$ & $\mathbf{\%}$ & $\mathbf{n}$ & $\mathbf{\%}$ & $\mathbf{n}$ & $\mathbf{\%}$ \\
\hline Laki-laki & 4 & 17,3 & 5 & 21,7 & 0 & 0 & 0 & 0 & 9 & 39,1 \\
\hline Perempuan & 0 & 0 & 11 & 47,8 & 3 & 13 & 0 & 0 & 14 & 60,9 \\
\hline Total & 4 & 17,3 & 16 & 69,5 & 3 & 13 & 0 & 0 & 23 & 100 \\
\hline$p$ value & \multicolumn{10}{|c|}{0,014} \\
\hline
\end{tabular}

Berdasarkan tabel 1 dapat diketahui bahwa sebanyak 11 orang pengrajin batik $(47,8 \%)$ di Virdes Batik Collection yang berjenis kelamin laki-laki mempunyai tingkat keluhan muskuloskeletal kategori sedang. Hasil uji statistik menggunakan Chi Square dengan menggunakan $\alpha 0,05$ didapatkan hasil nilai $p$ value 0,014 , karena nilai $p$ value < dari $\alpha$ maka terdapat hubungan antara jenis kelamin dengan keluhan muskuloskeletal pada pengrajin batik di Virdes Batik Collection.

Tabel 2. Hubungan Umur dan Keluhan Muskuloskeletal Pengrajin Batik Tulis

\begin{tabular}{|c|c|c|c|c|c|c|c|c|c|c|}
\hline \multirow{3}{*}{ Umur } & \multicolumn{10}{|c|}{ Keluhan Muskuloskeletal } \\
\cline { 2 - 12 } & \multicolumn{2}{|c|}{ Rendah } & \multicolumn{2}{c|}{ Sedang } & \multicolumn{2}{c|}{ Tinggi } & \multicolumn{2}{c|}{ Sangat Tinggi } & \multicolumn{2}{c|}{ Total } \\
\cline { 2 - 11 } & $\mathbf{n}$ & $\mathbf{\%}$ & $\mathbf{n}$ & $\mathbf{\%}$ & $\mathbf{n}$ & $\mathbf{\%}$ & $\mathbf{n}$ & $\mathbf{\%}$ & $\mathbf{n}$ & \% \\
\hline <30 Tahun & 4 & 17,3 & 2 & 8,6 & 0 & 0 & 0 & 0 & 6 & 26,1 \\
\hline$\geq 30$ Tahun & 0 & 0 & 14 & 60,8 & 3 & 13 & 0 & 0 & 17 & 73,9 \\
\hline Total & 4 & 17,3 & 16 & 69,5 & 3 & 13 & 0 & 0 & 23 & 100 \\
\hline
\end{tabular}

Berdasarkan tabel 2 dapat diketahui bahwa sebanyak 14 orang pengrajin batik $(60,8 \%)$ di Virdes Batik Collection yang mempunyai umur $\geq 30$ tahun mempunyai keluhan muskuloskeletal tingkat sedang.
Hasil uji statistik menggunakan Chi Square dengan menggunakan $\alpha 0,05$ didapatkan hasil nilai $p$ value 0,001 , karena nilai $p$ value < dari $\alpha$ maka terdapat hubungan antara umur dengan keluhan musculoskeletal pada pengrajin batik di Virdes Batik Collection. 
Tabel 3. Hubungan Masa Kerja dan Keluhan Muskuloskeletal Pengrajin Batik Tulis

\begin{tabular}{|l|c|c|c|c|c|c|c|c|c|c|}
\hline \multirow{3}{*}{ Masa Kerja } & \multicolumn{10}{|c|}{ Keluhan Muskuloskeletal } \\
\cline { 2 - 13 } & \multicolumn{2}{|c|}{ Rendah } & \multicolumn{2}{c|}{ Sedang } & \multicolumn{2}{c|}{ Tinggi } & \multicolumn{2}{c|}{ Sangat Tinggi } & \multicolumn{2}{c|}{ Total } \\
\cline { 2 - 12 } & $\mathbf{n}$ & $\mathbf{\%}$ & $\mathbf{n}$ & $\mathbf{\%}$ & $\mathbf{n}$ & $\mathbf{\%}$ & $\mathbf{n}$ & $\mathbf{\%}$ & $\mathbf{n}$ & \% \\
\hline$<5$ Tahun & 4 & 17,3 & 3 & 13 & 0 & 0 & 0 & 0 & 7 & 30,4 \\
\hline$\geq 5$ Tahun & 0 & 0 & 13 & 56,5 & 3 & 13 & 0 & 0 & 16 & 69,6 \\
\hline Total & 4 & 17,3 & 16 & 69,5 & 3 & 13 & 0 & 0 & 23 & 100 \\
\hline$p$ value & \multicolumn{10}{|c|}{0,003} \\
\hline
\end{tabular}

Berdasarkan tabel 3 dapat diketahui bahwa sebanyak 13 orang pengrajin batik $(56,5 \%)$ di Virdes Batik Collection yang mempunyai masa kerja $\geq 5$ tahun mempunyai keluhan muskuloskeletal tingkat sedang. Hasil uji statistik menggunakan Chi Square dengan menggunakan $\alpha \quad 0,05$ didapatkan hasil nilai $p$ value 0,003 , karena nilai $p$ value < dari a maka terdapat hubungan antara masa kerja dengan keluhan muskuloskeletal pada pengrajin batik di Virdes Batik Collection.

Tabel 4. Hubungan Kebiasaan Merokok dan Keluhan Muskuloskeletal Pengrajin Batik Tulis

\begin{tabular}{|l|c|c|c|c|c|c|c|c|c|c|}
\hline \multirow{3}{*}{$\begin{array}{c}\text { Kebiasaan } \\
\text { Merokok }\end{array}$} & \multicolumn{10}{|c|}{ Keluhan Muskuloskeletal } \\
\cline { 2 - 12 } & Rendah & \multicolumn{2}{c|}{ Sedang } & \multicolumn{2}{c|}{ Tinggi } & \multicolumn{2}{c|}{ Sangat Tinggi } & \multicolumn{2}{c|}{ Total } \\
\cline { 2 - 11 } & $\mathbf{n}$ & $\mathbf{\%}$ & $\mathbf{n}$ & $\mathbf{\%}$ & $\mathbf{n}$ & $\mathbf{\%}$ & $\mathbf{n}$ & $\mathbf{\%}$ & $\mathbf{n}$ & \% \\
\hline Iya & 0 & 0 & 5 & 21,7 & 0 & 0 & 0 & 0 & 5 & 21,7 \\
\hline Tidak & 4 & 17,3 & 11 & 47,8 & 3 & 13 & 0 & 0 & 18 & 78,3 \\
\hline Total & 4 & 17,3 & 16 & 69,5 & 3 & 13 & 0 & 0 & 23 & 100 \\
\hline$p$ value & \multicolumn{9}{|c|}{0,247} \\
\hline
\end{tabular}

Berdasarkan tabel 4 dapat diketahui bahwa sebanyak 11 orang pengrajin batik $(47,8 \%)$ di Virdes Batik Collection yang mempunyai kebiasaan merokok mempunyai keluhan muskuloskeletal tingkat sedang. Hasil uji statistik menggunakan Chi Square dengan menggunakan $\alpha \quad 0,05$ didapatkan hasil nilai $p$ value 0,247 , karena nilai $p$ value $>$ dari $\alpha$ maka tidak terdapat hubungan antara kebiasaan merokok dengan keluhan muskuloskeletal pada pengrajin batik di Virdes Batik Collection.

Tabel 5. Hubungan Sikap Kerja dan Keluhan Muskuloskeletal Pengrajin Batik Tulis

\begin{tabular}{|c|c|c|c|c|c|c|c|c|c|c|}
\hline \multirow{3}{*}{$\begin{array}{l}\text { Sikap } \\
\text { Kerja }\end{array}$} & \multicolumn{10}{|c|}{ Keluhan Muskuloskeletal } \\
\hline & \multicolumn{2}{|c|}{ Rendah } & \multicolumn{2}{|c|}{ Sedang } & \multicolumn{2}{|c|}{ Tinggi } & \multicolumn{2}{|c|}{ Sangat Tinggi } & \multicolumn{2}{|c|}{ Total } \\
\hline & $\mathbf{n}$ & $\%$ & $\mathbf{n}$ & $\%$ & $\mathbf{n}$ & $\%$ & $\mathbf{n}$ & $\%$ & $\mathbf{n}$ & $\%$ \\
\hline Rendah & 1 & 4,3 & 0 & 0 & 0 & 0 & 0 & 0 & 1 & 4,3 \\
\hline Sedang & 3 & 13 & 16 & 69,5 & 0 & 0 & 0 & 0 & 19 & 82,6 \\
\hline Tinggi & 0 & 0 & 0 & 0 & 3 & 13 & 0 & 0 & 3 & 13 \\
\hline Total & 4 & 17,3 & 16 & 69,5 & 3 & 13 & 0 & 0 & 23 & 100 \\
\hline p value & & & & & & 000 & & & & \\
\hline
\end{tabular}


Candralega, et al. Hubungan Karakteristik Individu dan Sikap Kerja Terhadap Keluhan Muskuskeletal Pada Pengrajin Batik Tulis

Berdasarkan tabel 5 dapat diketahui bahwa sebanyak 16 orang pengrajin batik $(69,5 \%)$ di Virdes Batik Collection yang mempunyai tingkat risiko sikap kerja sedang. Hasil uji statistik menggunakan Chi Square dengan menggunakan $\alpha 0,05$ didapatkan hasil nilai $p$ value 0,000 , karena nilai $p$ value $<$ dari $\alpha$ maka terdapat hubungan antara sikap kerja dengan keluhan muskuloskeletal pada pengrajin batik di Virdes Batik Collection.

\section{PEMBAHASAN}

Berdasarkan hasil penelitian menunjukkan sebagian besar pengrajin batik di Virdes Batik Collection berjenis kelamin perempuan dengan jumlah 11 orang pengrajin $(47,8 \%)$ mengalami keluhan muskuloskeletal tingkat sedang. Berdasarkan uji statistik didapatkan hasil bahwa terdapat hubungan antara jenis kelamin dengan keluhan muskuloskeletal pada pengrajin batik di Virdes Batik Collection dengan nilai $p=0,014$. Penelitian ini sejalan dengan penelitian yang dilaukan oleh Santosa dan Ariska (2018) pada pekerja batik di Sokaraja Banyumas yang menyatakan bahwa ada hubungan yang signifikan antara jenis kelamin dengan keluhan muskuloskeletal.

Menurut Tarwaka (2015) menyatakan bahwa secara fisiolgis kekuatan otot perempuan lebih rendah dibandingkan dengan kekuatan otot yang dimiliki oleh laki- laki. Diperkirakan kekuatan otot perempuan hanya 2/3 kekuatan otot laki-laki. Namun dibalik itu semua, menurut Mariska (2007) perempuan mempunyai tingkat ketelitian yang lebih tinggi dibandingkan dengan laki- laki. Hal tersebut dapat menjadi alasan mengapa pengrajin batik banyak didominasi oleh perempuan.

Hasil penelitian menunjukkan bahwa mayoritas pengrajin batik di Virdes Batik Collection mempunyai umur $>30$ tahun dengan jumlah 14 orang pengrajin $(60,8 \%)$ mengalami keluhan muskuloskeletal tingkat sedang. Berdasarkan uji statistik didapatkan hasil bahwa terdapat hubungan antara umur dengan keluhan muskuloskeletal pada pengrajin batik di Virdes Batik Collection dengan nilai $p=0,001$. Penelitian ini sejalan dengan penelitian yang dilakukan oleh Umami (2014) pada pengrajin batik tulis yang menyatakan bahwa ada hubungan antara umur dengan keluhan muskuloskeletal dengan nilai $p=0,031$
JPH RECODE Oktober 2018; 2 (1) : 1-10 http://e-journal.unair.ac.id/JPHRECODE

Umur sesorang mencapai masa puncaknya pada umur 25 tahun dan akan berbanding lurus dengan kapasitas fisiknya. Diusia 50-60 tahun kekuatan otot seseorang akan menurun sebesar $25 \%$ dan kemampuan fisik pada seseorang yang mempunyai umur $>60$ tahun akan menurun sebesar 50\% dibandingkan dengan sesorang yang mempunyai usia 25 tahun. Saat kekuatan otot menurun maka risiko untuk terkena kulahan muskuloskeletal akan semakin meningkat (Tarwaka, 2015).

Menurut Riihimäki H, et.al (1989) menyatakan bahwa umur mempunyai hubungan yang erat dengan keluhan muskuloskeletal, utamanya pada otot leher dan bahu, dan beberapa penelitian lainnya juga menyatakan bahwa umur merupakan penyebab utama timbulnya keluhan muskuloskeletal. Sanggar batik Virdes Batik Collection banyak memperkerjakan pengrajin yang mempunyai umur $\geq 30$ karena masyrakat disekitar sanggar batik kurang berminat untuk bekerja sebagai pengrajin batik.

Hasil penelititan menunjukkan bahwa mayorits pengrajin batik di Virdes Batik Collection mempunyai masa kerja $\geq 5$ tahun sebanyak 13 orang pengrajin $(56,5 \%)$ mengalami keluhan muskuloskeletal tingkat sedang. Berdasarkan uji statistik didapatkan hasil bahwa terdapat hubungan antara masa kerja dengan keluhan muskuloskeletal dengan nilai $p=0,003$. Penelitian ini sejalan dengan penelitian yang dilakukan oleh Hadyan dan Fitria Saftarina (2017) yang menyatakan bahwa ada hubungan antara masa kerja dengan keluhan muskuloskeletal dengan nilai $p=0,042$. Penelitian juga dilakukan oleh Umami (2014) pada pengrajin batik tulis yang menyatakan bahwa ada hubungan yang signifikan antara masa kerja dengan keluhan muskuloskeletal pada pengrajin batik.

Masa kerja mempunyai hubungan yang erat dengan terjadinya keluhan muskuloskeletal. Keluhan muskuloskeletal merupakan penyakit kronis yang yang mempunyai jangka waktu yang lama sehingga semakin lama seseorang bekerja maka semakin besar pula risiko untuk terjadinya keluhan muskuloskeletal. Hal 
Candralega, et al. Hubungan Karakteristik Individu dan Sikap Kerja Terhadap Keluhan Muskuskeletal Pada Pengrajin Batik Tulis

tersebut terjadi karena semakin lama mereka bekerja maka semakin lama pula kontrasi otot skeletal yang terjadi yang dapat mengakibatkan keluhan muskuloskeletal (Tarwaka, 2015). Hasil penelitian menunjukkan bahwa mayoritas pengrajin batik di Virdes Batik Collection yang tidak mempunyai kebiasaan merokok sebanyak 11 orang pengrajin $(47,8 \%)$ mengalami keluhan musculoskeletal ingkat sedang. Berdasarkan uji statistik didapatkan hasil bahwa tidak terdapat hubungan antara kebiasaan merokok dengan keluhan muskuloskeletal dengan nilai $p=$ 0,247 . Penelitian ini serupa dengan penelitian Ulvianingtias (2013) yang menunjukkan sebagian besar pekerja tidak mempunyai kebiasaan merokok dan hasil analisis menunjukkan bahwa tidak ada hubungan antara kebiasaan merokok dengan keluhan muskuloskeletal. penelitian ini tidak sejalan dengn penelitian yang dilakukan oleh Rahayu (2012) yang menyatakan bahwa ada hubungan yang signifikan antara kebiasaan merokok dengan keluhan muskuloskeletal dengan nilai $p=0,001$.

Menurut Tarwaka

menyatakan bahwa semakin tinggi frekuensi merokok pada seseorang, maka semakin tinggi pula risiko untuk terjadinya keluhan muskuloskeletal. Kebiasaan merokok berkaitan erat dengan kesegaran jasmani tubuh seseorang. Kebiasaan merokok dapat menyebabkan turunnya kapasitas dari paruparu, sehingga kemampuan untuk mengkonsumsi oksigen akan menurun, sehingga berdampak pada tingkat kesegaran tubuh juga akan menurun. Apabila seseorang bekerja dituntut untuk mengerahkan tenaga, maka seseorang tersebut akan mudah lelah. Hal ini karena ketika seseorang mengalami kelelahan maka kandungan oksigen dalam darah mnejadi rendah, kemudian pembakaran karbohidrat menjadi terhambat. Sehingga mengakibatkan penumpukan asam laktat yang menimbulkan rasa nyeri (Tarwaka, dkk., 2004). Pengrajin batik Virdes Batik Collection banyak yang tidak merokok dikarenakan mayoritas pengrajin mempunyai jenis kelamin wanita dan wanita di Indonesia sangat jarang memiliki kebiasaan merokok.

Hasil penelitian mengenai sikap kerja menunjukkan bahwa mayoritas pengrajin batik di Virdes Batik Collection mempunyai risiko
JPH RECODE Oktober 2018; 2 (1) : 1-10 http://e-journal.unair.ac.id/JPHRECODE

sikap kerja sedang sebanyak 16 orangorang pengrajin $(69,5 \%)$ mengalami keluhan muskuloskeletal tingkat sedang. Berdasarkan uji statistik didapatkan hasil bahwa terdapat hubungan antara sikap kerja dengan keluhan muskuloskeletal dengan nilai $p=0,000$. Penelitian ini setara dengan penelitian yang dilakukan oleh Santosa dan Ariska (2018) yang menyatakan bahwa adanya hubungan yang kuat antara sikap kerja dengan keluhan muskuloskeletal pada pengrajin batik dengan nilai $p=0,01$. Penelitian juga dilakukan Umami (2014) yang menyatakan bahwa terdapat hubungan yang signifikan antara sikap kerja dengan keluhan muskuloskeletal dengan nilai $p=0,018$.

Menurut Tarwaka (2015) menyatakan bahwa sikap kerja tidak alamiah terjadi akibat stasiun kerja yang tidak sesuai dengan ukuran antropometri pekerja. Hasil pengamatan yang telah dilakukan di Virdes Batik Collection didapatkan bahwa banyak stasiun kerja yang tidak sesuai dengan ukuran antropometri pekerja. Misalnya kursi yang digunakan untuk membatik terlalu kecil dan pendek, meja yang digunakan untuk proses pewarnaan pada kain juga mempunyai ukuran yang pendek. Hal tersebut menyebabkan pengrajin batik bekerja dengan posisi sedikit membungkuk dan apabila dibiarkan dalam waktu yang cukup lama dapat berpotensi untuk menyebabkan keluhan muskuloskeletal.

Beberapa sikap kerja yang dilakukan oleh pengrajin batik banyak yang menjauhi pusat gerak atau tidak bekerja dalam posisi normal. Hal tersebut dilakukan seperti saat melakukan kegiatan mencanting dan mewarnai kain, posisi tubuh mengharuskan untuk menjangkau semua bagian kain, dalam posisi duduk dalam waktu yang lama. Sikap kerja yang tidak alamiah tersebut apabila tidak segera ditangani akan dapat mengakibatkanterjadinya ketegangan pada otot, tendon, dan ligamen (Tarwaka, dkk., 2004).

Kelebihan dan kekurangan pada penelitian ini. Kelebihan dari penelitian ini yaitu penelitian ini dapat dilakukan dengan cepat dan mudah, serta tidak memakan 
banyak biaya. Hasil dari penilaian muskuloskeletal ini juga bisa langsung didapat dengan cepat. Kekurangan pada penelitian ini yaitu peneliitian ini bersifat subyektif jadi untuk tingkat keluhan yang dirasakan tiap pengrajin batik berbeda-beda sehingga tidak dapat dijadikan sebagai pedoman untuk tingkat keluhan muskuloskeletal yang sesungguhnya. Penilaian juga hanya dengan menggunakan metode wawancara sehingga tingkat kejujuran dari responden juga berbeda-beda.

\section{KESIMPULAN DAN SARAN}

Berdasarkan hasil penelitian yang dilakukan di Virdes Batik Collection dapat disimpulkan bahwa mayoritas pengrajin batik yang berjenis kelamin perempuan, mempunyai umur $\geq 30$ tahun, mempunyai masa kerja $\geq 5$ tahun dan tidak mempunyai kebiasaan merokok mengalami keluhan muskuloskeletal tingkat sedang. Sikap kerja yang dilakukan pengrajin batik di Virdes Batik Collection mayoritas mempunyai tingkat risiko sedang mengalami keluhan muskuloskeletal tingkat sedang. Berdasarkan uji statistik didapatkan hasil bahwa terdapat hubungan antara jenis kelamin, umur, masa kerja dan sikap kerja dengan keluhan muskuloskeletal. Namun tidak terdapat hubungan antara kebiasaan merokok dengan keluhan muskuloskeletal.

Diharapkan pemilik sanggar batik Virdes Batik Collection lebih memperhatikan kesehatan pekerjanya serta memberikan intervensi terkait keluhan muskuloskeletal yang dirasakan oleh pengrajin batik. Intervensi yang dapat dilakukan oleh pemilik sanggar batik yaitu dengan melakukan perancangan ulang stasiun kerja dengan desain yang sesuai dengan ukuran antropometri pengrajin batik. Dari hasil perancangan ulang stasiun kerja diharapkan sikap kerja pengrajin batik dapat bekerja secara alamiah dan ergonomis agar keluhan muskuloskeletal yang dirasakan oleh pengrajin batik dapat berkurang.

\section{DAFTAR PUSTAKA}

Hadyan, M. F. dan F. S. 2017. Hubungan Usia, Lama Kerja, Masa Kerja dan Indeks Massa Tubuh (IMT) terhadap Kejadian Low Back Pain (LBP) pada Petani di Desa Munca Kabupaten Pesawaran. Medula, 7(4).

Lindawati. 2015. Evaluasi Postur Kerja dan Stasiun Kerja Membatik pada Pengrajin
Batik Tulis di Alleya Batik Gunung Kidul. Skripsi. Universitas Airlangga.

Mariska, D. 2007. Karier Wanita dan Faktor-faktor yang berpengaruh dalam proyek konstruksi. Thesis. Universitas Petra Christian.

Nurdin, K. O. 2015. Analisis Karakteristik Individu dan Stasiun Kerja terhadap Keluhan Subjektif Muskuloskeletal (Studi pada Pekerja Pengguna Komputer di Malang Pos). Skripsi. Universitas Airlangga.

Rahayu, W. A. 2012. Faktor-faktor yang Berhubungan dengan Keluhan Muskuloskeletal pada Pekerja Angkatangkut Industri Pemecahan Batu di Kecamatan Karangnongko Kabupaten Klaten. Jurnal Kesehatan Masyarakat Universitas Diponegoro, 1(2).

Restuputri, D. P. 2018. Penilaian Risiko Gangguan Musculoskeletal Disorder Pekerja Batik Dengan Menggunakan Metode Strain index. Jurnal Teknik Industri, 19(1), pp. 97-106. doi: 10.22219/jtiumm.vol19.no1.99-109.

Riihimäki H, Tola S, Videman T, H. K.. 1989. Lowback pain and occupation: A cross-sectional questionnaire study of men in machine operating, dynamic physical work, and sedentary work. National Center for Biotechnology Information, 14(2). Diakses dari: https://www.ncbi.nlm.nih.gov/pubmed/ 2522244.

Santosa, A. dan Ariska, D. K. 2018. FaktorFaktor Yang Berhubungan Dengan Kejadian Musculoskeletal Disorders Pada Pekerja Batik Di Kecamatan Sokaraja Banyumas Agus Santosa 1, Dwi Kuat Ariska 1 1. MEDISAINS: Jurnal Ilmiah Ilmu-ilmu Kesehatan, 16(1), pp. 42-46. doi: 10.30595/medisains.v16i1.2559.

Savitri,I.W, Hardian., dan Sumekar, T. A. 2015. Hubungan antara Aktivitas Membatik dengan Gangguan Sistem Muskuloskeletal pada Pengrajin Batik Tulis, Media Muda Medika. Media Muda Medika, 4(4), pp. 985-995.

Senjayani dan Tri Martiana. 2017. Penilaian Dan Pengendalian Risiko Pada Pekerjaan Bongkar Muat Peti Kemas Oleh Tenaga Kerja Bongkar Muat 
Dengan Crane. Journal of Public Health Research and Community Health Development, 1(2), pp. 119-129.

Tarwaka, Bakri, S.H.A, dan Sudiajeng, L. 2004. Ergonomi untuk Keselamatan, Kesehatan Kerja dan Produktivitas. [e-book] Surakarta: UNIBA Press.

Tarwaka. 2015. Ergonomi Industri, Dasardasar Pengetahuan dan Aplikasi di Tempat Kerja. Surakarta: Harapan Press. doi: 10.1007/978-1-4684-0104-2_6.

Ulvianingtias, L. 2013. Analisis Karakteristik Individu dan Stasiun Kerja terhadap Keluhan Subjektif Muskuloskeletal Disorders (MSDs) pada Pengguna Komputer di Rumah Sakit Muhammadiah Lamongan. Skripsi. Universitas Airlangga. Diakses dari: http://repository.unair.ac.id/22596/.

Umami, D. 2014. Hubungan antara Karakteristik Responden dan Sikap Kerja Duduk dengan Keluhan Nyeri Punggung Bawah (Low Back Pain) Pada Pekerja Batik Tulis. Pustaka Kesehatan.

Zakaria, I. F. 2016. Faktor yang berhubungan dengan keluhan muskuloskeletal Disorders pada pekerja bongkar muat PT. Pelindo III Tanjung Perak Surabaya. Skripsi. Universitas Airlangga. Diakses dari: http://repository.unair.ac.id/40028/. 